\title{
COMPARISON OF CROATIAN AND EUROPEAN STANDARDS FOR DETERMINING THE FROST SUSCEPTIBILITY OF HYDRAULICALLY BOUND MIXTURES
}

\author{
Elena Ovad \\ Josip Juraj Strossmayer University of Osijek, Faculty of Civil Engineering Osijek, student \\ Ivana Barišić \\ Josip Juraj Strossmayer University of Osijek, Faculty of Civil Engineering Osijek, Assistant Professor \\ Corresponding author: ivana@gfos.hr \\ Martina Zagvozda \\ Josip Juraj Strossmayer University of Osijek, Faculty of Civil Engineering Osijek, mag.ing.aedif.
}

\begin{abstract}
The base layer of a multi-layered pavement structure is often a cement-bound material, which combines an aggregate with cement binder. This load-bearing layer is quite rigid, which improves pavement properties, including frost resistance, and extends the life cycle of the pavement. In geographic areas with low temperatures and significant ground water, the bearing capacity of pavement structures can be reduced by volume deformations from freezing and thawing. Cold winters and frost-susceptible soil are present in eastern Croatia and in the city of Osijek. Thus, in this paper we examine the frost susceptibility of cement-bound aggregates, made with materials commonly used in Croatia, in accordance with the current Croatian standard HRN U.B1.050 and a new European standard EN 13286-54. The test mixtures did not meet the conditions for frost-resistant materials. To meet these conditions, one must use a higher cement ratio or a cement with a higher strength class.
\end{abstract}

Keywords: freeze-thaw resistance, cement-bound aggregate, pavement structure, standards

\section{USPOREDBA REZULTATA ISPITIVANJA OTPORNOSTI NA SMRZAVANJE HIDRAULIČNIM VEZIVOM VEZANIH MJEŠAVINA PREMA HRVATSKOJ I EUROPSKOJ NORMI}

Sažetak: Cementom stabilizirani materijal je nosivi sloj višeslojne kolničke konstrukcije, koji je kombinacija agregata s cementom kao vezivom. Ovaj nosivi sloj ima znatnu čvrstoću, poboljšava određena svojstva kolnika kao što su osjetljivost na smrzavanje te produljenje vijeka trajanja kolnika. Formiranje leda, volumne deformacije te gubitak nosivosti prilikom odmrzavanja u proljeće česta su pojava u područjima s niskim temperaturama i visokim razinama podzemne vode. Stoga je prilikom projektiranja kolničke konstrukcije u obzir potrebno uzeti ne samo prometno opterećenje, već i oštre klimatske i okolišne čimbenike. Hladne zime i tlo osjetljivo na mraz prisutni su u istočnoj Hrvatskoj i gradu Osijeku. Stoga ovaj rad istražuje osjetljivost na smrzavanje cementom stabiliziranog agregata prema staroj hrvatskoj normi HRN U.B1.050 i novoj europskoj normi EN 13286-54. Radi usporedbe ove dvije norme korišteni su materijali koji se uobičajeno koriste u Republici Hrvatskoj za izradu ovih slojeva. Rezultati su pokazali kako niti jedna mješavina ne zadovoljava uvjete postavljene normama te da je potrebno koristiti cement veće klase ili povećani udio cementa kako bi se dobio materijal otporan na utjecaj smrzavanja i odmrzavanja.

Ključne riječi: otpornost na smrzavanje-odmrzavanje, cementom stabilizirani agregat, kolnička konstrukcija, norme 
Comparison of Croatian and European standards for determining the frost susceptibility of

\section{INTRODUCTION}

Pavement structures are multi-layered systems of different materials mechanically compacted into interconnected layers. The pavement materials, layer thicknesses, and layer compositions depend on the traffic load, characteristics of the base soil, and the environment.

The base layer of pavement structures often use cement-bound materials, comprising an aggregate and cement as the binder, which improves properties such as bearing capacity and frost susceptibility. A load-bearing cement-bound layer is made using granular stone, cement of certain strength classes, and water [1]. The granular aggregate can be natural sandy gravel, crushed stone, or sand with specific grading. The binder is often cement of lower strength class, commonly 32.5 or 42.5 , with a density of $50-100 \mathrm{~kg} / \mathrm{m}^{3}$.

Layers of cement-bound granular materials are quite rigid, providing an ideal base for flexible asphalt pavements, extending their life cycle. When designing a pavement structure, it must be able to withstand the necessary traffic load as well as the environment. Low temperatures cause the most damage if water is present in the soil; freezing and thawing causes volume deformations, decreasing the bearing capacity of the pavement structure [2]. Freezing comprises two interrelated processes: freezing swells and uplifts (denivelates) the soil, and thawing reduces the soil strength. Freezing weakens the structure by forming ice lenses, while thawing forms cracks and ruts [3]. To design a pavement structure to withstand freezing and thawing, one must account for the depth of soil freezing and apply and a buffer base layer of cement-bound materials. Pavement structures with cement-bound layers are less sensitive to seasonal influences and experience less deformation and material fatigue [4].

For cement-bound materials to be used properly new and existing roads, construction standards must define the required resistance of cement-bound materials to freezing and thawing. These requirements are especially necessary in continental areas with cold winters, adverse climatic conditions, and soils susceptible to frost, such as eastern Croatia. Tables 1 and 2 show the effects of harsh climate in Croatia, presenting the mean monthly temperature in Osijek and the number of days with temperatures below $0{ }^{\circ} \mathrm{C}$ in $2008-2012$. The mean monthly air temperature can reach below $0{ }^{\circ} \mathrm{C}$ during January and February, and air temperatures below $0{ }^{\circ} \mathrm{C}$ occur during three to five months of the year. During these periods, the highest mean temperatures are 21-24 ${ }^{\circ} \mathrm{C}$. Table 2 shows that March has experienced air temperatures below $0{ }^{\circ} \mathrm{C}$, just before spring thawing, suggesting a higher risk for pavement to form cracks and ruts.

Table 1 Mean monthly temperature $\left({ }^{\circ} \mathrm{C}\right)$ in Osijek

\begin{tabular}{ccccccccccccc} 
Year/Month & $\mathbf{I}$ & II & III & IV & V & VI & VII & VIII & IX & X & XI & XII \\
\hline $\mathbf{2 0 0 8}$ & 1.50 & 4.90 & 7.60 & 12.50 & 18.10 & 21.50 & 21.80 & 21.80 & 15.60 & 13.00 & 7.50 & 3.80 \\
$\mathbf{2 0 0 9}$ & -1.10 & 2.30 & 6.80 & 14.60 & 18.30 & 19.20 & 23.20 & 22.90 & 19.10 & 11.50 & 8.20 & 3.10 \\
$\mathbf{2 0 1 0}$ & -0.80 & 1.40 & 6.80 & 12.40 & 16.50 & 20.40 & 23.20 & 21.70 & 15.60 & 9.10 & 8.90 & 0.20 \\
$\mathbf{2 0 1 1}$ & 1.10 & 0.70 & 6.40 & 13.20 & 16.70 & 20.80 & 22.20 & 23.00 & 20.30 & 10.60 & 2.30 & 3.40 \\
$\mathbf{2 0 1 2}$ & 2.20 & -4.10 & 8.70 & 12.50 & 16.90 & 22.50 & 24.80 & 24.10 & 18.90 & 12.10 & 9.00 & 0.40
\end{tabular}

Table 2 Number of days with temperatures below $0^{\circ} \mathrm{C}$ in Osijek

\begin{tabular}{ccccccccccccc} 
Year/Month & I & II & III & IV & V & VI & VII & VIII & IX & $\mathbf{X}$ & $\mathbf{X I}$ & XII \\
\hline $\mathbf{2 0 0 8}$ & 7 & 5 & 0 & 0 & 0 & 0 & 0 & 0 & 0 & 0 & 0 & 6 \\
$\mathbf{2 0 0 9}$ & 19 & 8 & 0 & 0 & 0 & 0 & 0 & 0 & 0 & 0 & 0 & 8 \\
$\mathbf{2 0 1 0}$ & 15 & 13 & 3 & 0 & 0 & 0 & 0 & 0 & 0 & 0 & 0 & 16 \\
$\mathbf{2 0 1 1}$ & 13 & 11 & 7 & 0 & 0 & 0 & 0 & 0 & 0 & 0 & 13 & 5 \\
$\mathbf{2 0 1 2}$ & 8 & 18 & 1 & 0 & 0 & 0 & 0 & 0 & 0 & 0 & 0 & 12
\end{tabular}

The freeze-thaw cycle test is mostly used in civil engineering to evaluate how freeze-thaw cycles affect the performance of cement concrete, soil [5, 6], and more recently asphalt pavement [7]. Because salt is often used as a de-icing agent, it must be accounted for when analyzing freeze-thaw resistance because a saline gradient can increase the frost susceptibility of materials [2].

The current Croatian standard HRN.U.B1.050 [9] will soon be replaced with the new European Standard EN 13286-54 [8]. Because of this development, in this paper we compare the frost susceptibility of cement-bound gravel aggregates based on the current and new standards, taken from previous research [10, 11]. 


\section{STANDARDS FOR FREEZE-THAW RESISTANCE DETERMINATION OF CEMENT- BOUND AGGREGATE}

\subsection{Croatian standard HRN U.B1.050}

The standard HRN U.B1.050 prescribes a method for testing the frost resistance of cement-stabilized soil in order to determine the minimum required quantity of cement to make a pavement structure with the required freezing resistance. In this standard, frost susceptibility is examined in two ways: by determining changes in volume and mass, and by determining the reduction in compressive strength.

For both methods, a freeze-thaw cycles consists of freezing for $16 \mathrm{~h}$ at $-10^{\circ} \mathrm{C}$ to $-15^{\circ} \mathrm{C}$ (this temperature depends on the degree to which the material in the pavement structure is exposed to frost) and defrosting for $8 \mathrm{~h}$ at $20 \pm 2{ }^{\circ} \mathrm{C}$. Samples are exposed to 14 freeze-thaw cycles. If, after 6 cycles, the sample is damaged, the proportion of cement is deemed insufficient.

To determine the volume change, the volume of the specimen is calculated as follows:

$\Delta V=\frac{V-V_{1}}{V} \times 100$

where $\Delta V$ is the volume change [\%], $V$ is the specimen volume before freeze-thaw cycling [cm $\left.\mathrm{cm}^{3}\right]$, and $V_{1}$ is the volume of the specimen after freeze/thaw cycling $\left[\mathrm{cm}^{3}\right]$. A cement-bound material is considered frost-resistant if it has a maximum volume change of $2 \%$.

To determine the mass change, the specimen is weighted and mass loss is calculated as follows:

$\Delta m=\frac{m-m_{1}}{m} \times 100$

where $\Delta m$ is the mass change [\%], $m$ is the specimen mass before freeze-thaw cycling [g], $m_{1}$ is the specimen mass after freeze/thaw cycling [g]. A cement-bound material is considered is frost-resistant if it has a maximum mass loss of $7 \%$ (clay materials) or $14 \%$ (sandy gravel).

In the second method, after 14 freeze/thaw cycles the specimens tested for compressive strength. The frost susceptibility index $R$ is then calculated as follows:

$R=\frac{p}{p_{1}} \times 100$

where $p$ is the compressive strength after exposure to freeze/thaw cycling [N/mm²], $p_{1}$ is the compressive strength of the control specimen [ $\left.\mathrm{N} / \mathrm{mm}^{2}\right]$. A cement-bound material is considered frost-resistant if it has a minimum frost susceptibility index $R$ of $80 \%$. Because cement-bound tend to have uncontrolled surface crush because of their granular composition, in this work we used the second method, measuring the loss in compressive strength.

\subsection{European standard EN 13286-54}

After curing for 28 days, the two sets of test specimens are removed from their molds and placed in a water bath for 2 days for further curing. After this second curing, one set of three test specimens (Set $A$ ) is removed from the bath; these samples are then dried on their surfaces and tightly wrapped in plastic film. The second set (Set B) remains in water bath, acting as the control. The Set A specimens are placed in a freeze-thaw cabinet and subjected to 10 freeze-thaw cycles, then unwrapped and returned to the water bath for 1 day to ensure complete thawing. Then, the strengths of Set $A$ and $B$ are measured. The frost susceptibility index $R$ is calculated as follows:

$R F T=\frac{M_{A}}{M_{B}} \times 100$

where $M_{A}$ is the mean compressive strength of Set $A[M P a]$ and $M_{B}$ is the mean compressive strength of Set $B$ [MPa]. 
Comparison of Croatian and European standards for determining the frost susceptibility of hydraulically bound mixtures

This standard also defines a method to determine the frost susceptibility for materials when they experience frequent freeze-thaw cycling in the presence of sea water spray or abundant de-icing salt solution. In this case, the water in the second stage of curing is replaced with a solution of $1 \%$ sodium chloride $(\mathrm{NaCl})$.

\section{EXPERIMENTAL PROGRAM}

\subsection{Material characterization}

The aggregate was natural river gravel, a natural material commonly used in road construction in Croatia. This grey-brown gravel had a grain size of $\mathrm{D}_{50}=6 \mathrm{~mm}$ and a degree of non-uniformity of $\mathrm{U}=\mathrm{d}_{60} / \mathrm{d}_{10}=20$.

Figure 1 shows the particle-size distribution curves for the aggregate. The binder was Portland cement of grade 32.5 (CEM II B/M (P-S) $32,5 R$ ), comprising $2 \%$ or $4 \%$ of the aggregate mass.

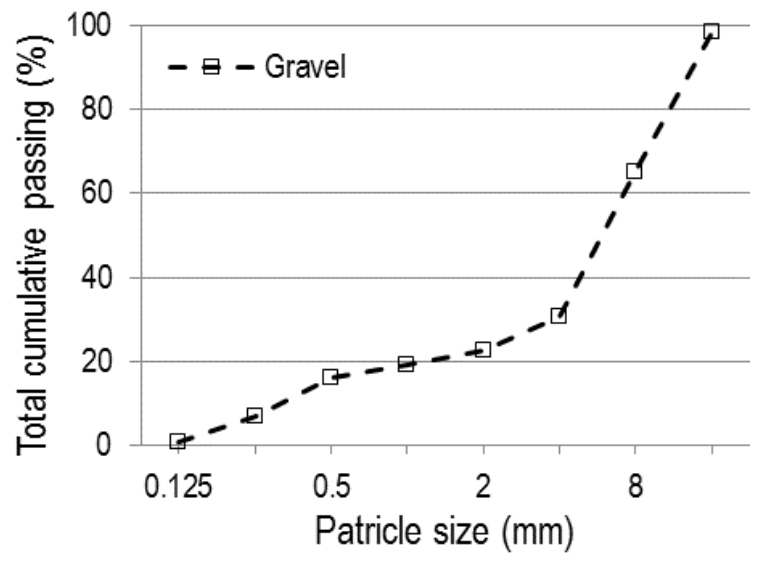

Figure 1 Particle-size distribution curve for the gravel aggregate

\subsection{Proctor compaction test - reference density and water content}

The Proctor compaction test, defined by standard EN 13286-2, was used to determine the relationship between the water content and the dry density of the hydraulically bound mixtures after compaction. Using this test, one can estimate the mixture density that can be achieved on construction sites and provides a reference parameter for assessing the density of the compacted layer. This method also provides data on the range of water content in which the mixtures can be satisfactorily compacted to a given dry density.

According to standard EN 13286-2, cement-bound gravel can be characterized as a self-draining mixture for which water loss occurs during compaction. This phenomenon means the maximum dry density cannot be defined using the standard Proctor curve, as shown in Figure 2.

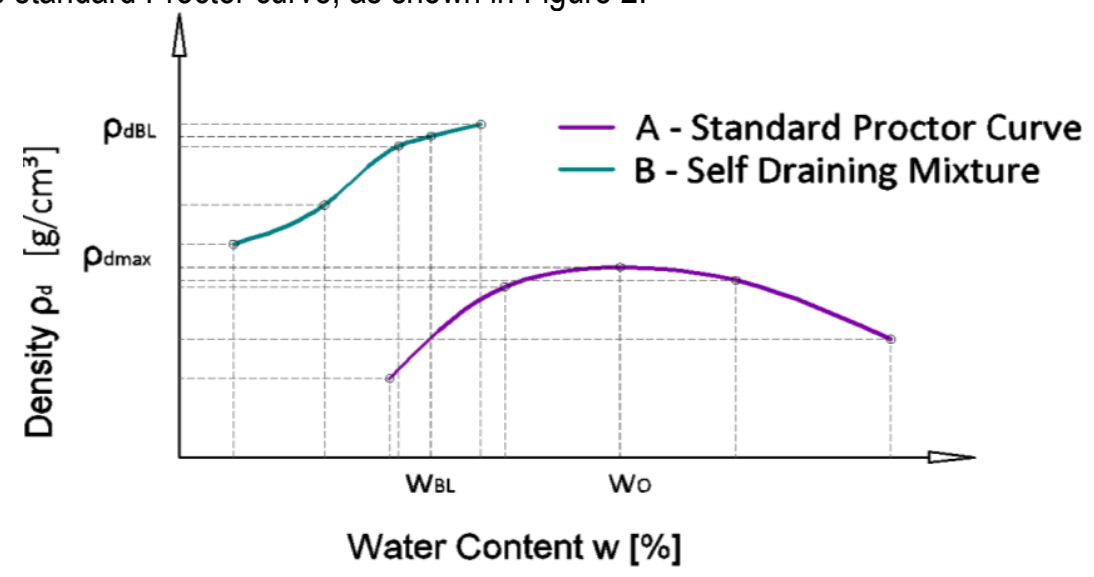

Figure 2 Standard Proctor curve and curve for self-draining mixtures 
Instead, the material was compacted and characterized using the modified Proctor test to determine the dry density required for the mixture to lose $0.3-0.5 \%$ of its water during compaction. The maximum initial water content for which there is no water loss during compaction is defined as the "bleeding water content"; i.e., the optimal water content. The laboratory reference dry density of the self-draining mixture is defined as the "dry density at bleeding"; i.e., the maximum dry density.

\subsection{Sample preparation and treatment}

The relationship between moisture content and dry density was determined by the modified Proctor compaction test (specific compaction energy of $\sim 2.7 \mathrm{MJ} / \mathrm{m}^{3}$ ), according to EN 13286-2. Using this relationship, we calculated the optimum moisture content (OMC) and maximum dry density (MDD).

The specimens were prepared at their respective OMCs and MDDs according to EN 13286-50. The compacted specimens were cylindrical, $100 \mathrm{~mm}$ in diameter, and $120 \mathrm{~mm}$ in height. The prepared specimens were cured for 28 days in a chamber held at $20^{\circ} \mathrm{C}$, wrapped in plastic to prevent moisture loss.

\subsection{Measurement of compressive strength}

According to EN 14227-1, the mechanical properties of cement-bound base courses are classified by their compressive strength after curing for 28 days. Croatian standards [1] use the compressive strength after curing for 7 and 28 days. For these experiments, we tested the compressive strength after curing for 28 days.

The compressive strength of each cured specimen was determined, according to EN 13286-41, as the average stress in the specimen upon stress fracture when exposed to uniaxial pressure. Figure 3 shows the procedure used to test the compressive strength.

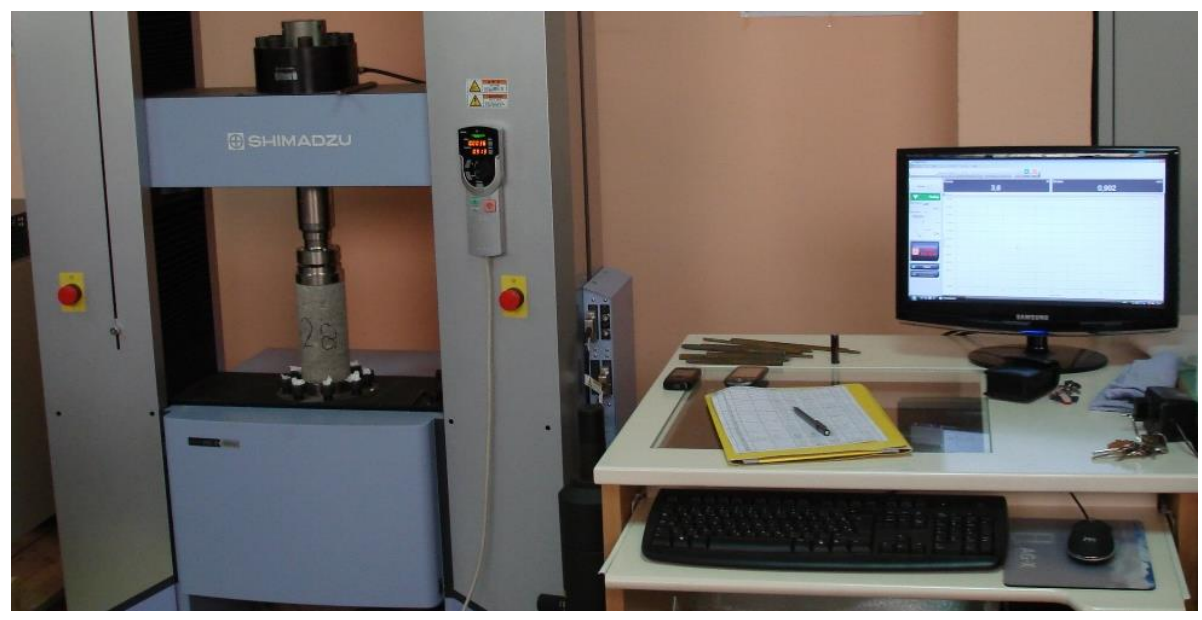

Figure 3 Equipment used to test compressive strength

The load during the test was applied continuously and uniformly, without shock, and rupture occurred within 30-60 s after loading began. We calculated the compressive strength as follows:

$$
\mathrm{R}_{\mathrm{c}}=\frac{\mathrm{F}}{\mathrm{A}_{\mathrm{c}}}
$$

where $R_{c}$ is the compressive strength [N/mm²], $F$ is the maximum registered force $[N]$, and Ac is the crosssectional area of the specimen [mm²]. 
Comparison of Croatian and European standards for determining the frost susceptibility of hydraulically bound mixtures

\section{RESULTS AND DISCUSSION}

Table 3 shows the measured properties of the mixtures.

Table 3 Properties of cement-bound gravel aggregates

\begin{tabular}{lllllll} 
cement content & OMC [\%] & $\operatorname{MDD}\left[\mathrm{g} / \mathrm{cm}^{2}\right]$ & $f_{\mathrm{c}}[\mathrm{MPa}]$ & $R_{\mathrm{HRN}}[\%]$ & $R_{\text {EN }}[\%]$ & $R_{\text {EN,salt }}[\%]$ \\
\hline $\mathbf{2} \%$ & 3.78 & 2.075 & 1.287 & 86.25 & 74.56 & 100 \\
$\mathbf{4} \%$ & 4.52 & 2.13 & 2.994 & 45.76 & 67.45 & 100
\end{tabular}

OMC - optimal moisture content

MDD - maximum dry density

$f_{c}$ - compressive strength at 28 days

$R_{\text {HRN }}$ - retained strength factor after freeze-thaw testing, according to the Croatian standard HRN U.B1.050

$R_{E N}$ - retained strength factor after freeze-thaw testing, according to the European standard EN 13286-54

$R_{\mathrm{EN}, \text { salt }}$ - retained strength factor after freeze-thaw testing in the presence of de-icing agent (salt), according to EN 13286-54

\subsection{Proctor compaction test - reference density and water content}

The Proctor compaction test defined by standard EN 13286-2 was used to determine the relationship between the water content and the dry density of hydraulically bound mixtures, as described in section 3.2. Figure 4 shows these results.

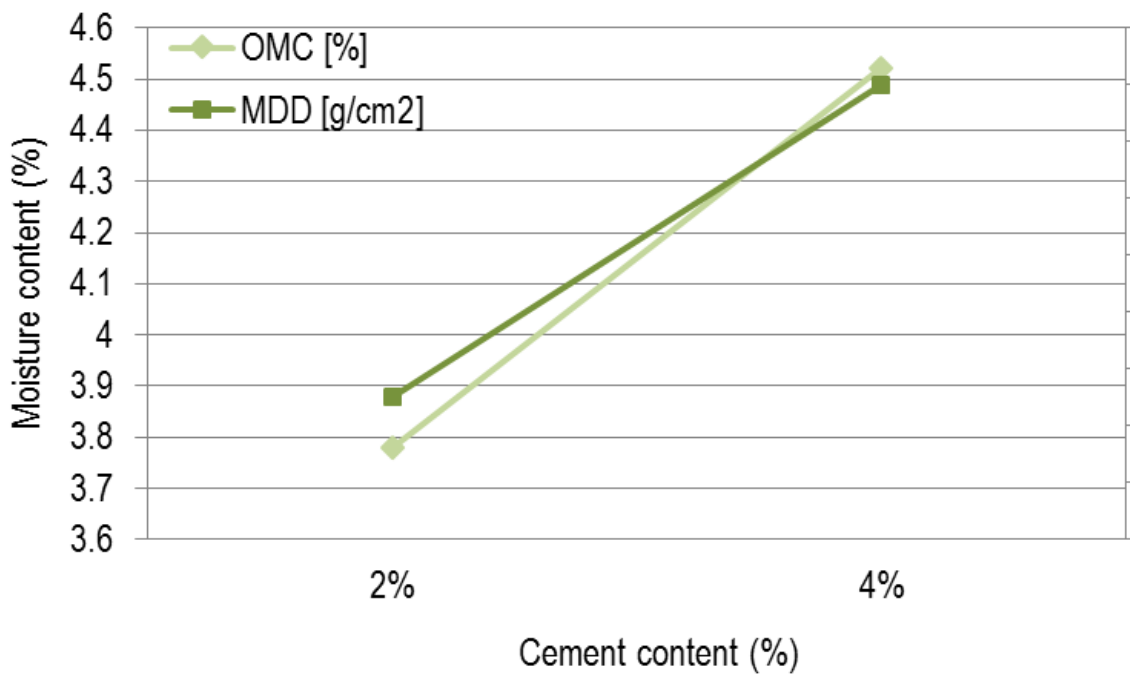

Figure 4 Results of Proctor compaction test

Increasing the cement content increased the optimal moisture content and maximum dry density. These results are expected because higher cement contents necessitate more moisture in order to produce the cement hydration reaction and to create the cement paste. A higher cement content creates more cement paste, which lubricates the aggregate grains and leads to better mixture compaction because the finer cement particles fill the voids in the aggregate matrix.

\subsection{Compressive strength}

The compressive strength of each mixture was determined as the mean of the compressive strength after curing for 28 days, measured from three samples for each set (Table 3). Increasing the cement content from $2 \%$ to $4 \%$ increased the compressive strength by $42.99 \%$. This result is well expected and caused by cement hydration. Specifically, calcium silicate hydrates (C-S-H) [12] strongly influence the compressive strength of the mixture [13]. 
As the cement content increases, more $\mathrm{C}-\mathrm{S}-\mathrm{H}$ gels form, increasing the compressive strength. However, when choosing the optimum amount of Portland cement, it is not cost effective to select the highest percentage of cement because mixtures with higher cement content are vulnerable to shrinkage cracks, a major problem for pavement that experiences water infiltration [14].

We compared the compressive strengths of these mixtures to the required compressive strength according to the Croatian regulations [1] and the European standard EN 14227-1 after curing for 28 days. According to Croatian regulations, cement-bound aggregates used as pavement base courses must have a 28-day compressive strength of 2.5-6.5 MPa, depending on the expected traffic load. As shown in Table 3, mixes with $2 \%$ cement did not meet the strength criterion, while the mix with $4 \%$ cement met the criteria for heavily trafficked roads. The European standard EN 14227-1 classifies hydraulically bound mixes into strength classes, similar to concrete classes. Based on this standard, the mix with $2 \%$ cement is classified as strength class $\mathrm{C}_{0}$, while the mix with $4 \%$ cement is classified as strength class $C_{1,5 / 2}$. The European regulations provide detailed classifications of cement-bound aggregates according to their compressive strength, letting us more precisely define the potential applications of the building materials in this report.

\subsection{Freeze-thaw resistance, HRN U.B1.050}

Table 3 shows the freeze-thaw resistance of the cement-bound aggregates tested in accordance with Croatian standard HRN U.B1.050, as described in section 2.1, done by assessing the loss of compressive strength. A cement-bound aggregate mixture is considered freeze-thaw resistant if it has a retained strength factor of $R \geq$ $80 \%$. The mixture with $2 \%$ cement satisfied this requirement, while the mixture with $4 \%$ cement did not.

Results of freeze-thaw resistance need to be commented taking into account the testing of compressive strength. In fact, according to EN 13286-41, compressive strength is determined by three kinds of samples. When calculating compressive strength, if a result deviates by more than $20 \%$ compared to the other two results, it is discarded. In some of our measurements of compressive strength, the results of the three specimens varied up to $60 \%$. For measurements where the lowest and highest results differ from the middle result by more than $20 \%$, the compressive strength can be calculated using the middle and higher result or the middle and lower result. At the same time, the standard for determining the freeze-thaw resistance defines an allowed strength loss of $20 \%$.

\subsection{Freeze-thaw resistance, EN 13286-54}

Table 3 shows the freeze-thaw resistance of cement-bound aggregate tested in accordance to European standard EN 13286-54, as described in section 2.2. This test was done over 14 freeze-thaw cycles, both with and without a de-icing agent. A cement-bound aggregate mixture is considered freeze-thaw resistant for a retained strength factor of $R \geq 80 \%$. Neither mixture met the requirements of this standard. In the presence of salt, all the specimens were extremely damaged by freeze-thaw testing (Fig. 5), so we could not determine their compressive strength and frost susceptibility index. From these results, we conclude that neither mixture was frost-resistant. The specimens tested in accordance with EN 13286-54 were damaged much more than those tested in accordance with HRN U.B1.050.

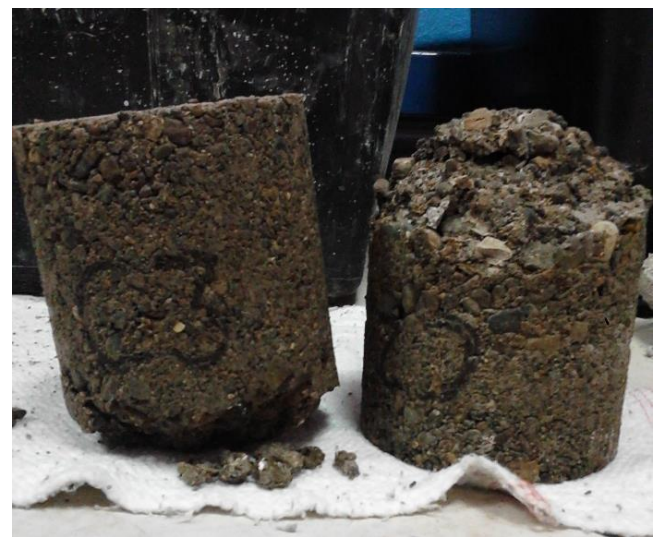

Figure 5 Specimens damaged from freeze/thaw cycling in the presence of salt 
Comparison of Croatian and European standards for determining the frost susceptibility of

\section{CONCLUSION}

It is important to measure and control the resistance of cement-bound materials to freezing and thawing, especially in continental areas with cold winters adverse climates, and soils susceptible to frost. These conditions are present in eastern Croatia, so in this paper we aimed to define the frost susceptibility of cement-bound aggregates, using materials common in Croatian road construction, in accordance with the current Croatian standard HRN U.B1.050 and the new European standard EN 13285-54. These standards differ in how they determine the compressive strength of the control mixture and whether they recognize the influence of de-icing agents.

Salt, a commonly used de-icing agent in Croatia, can transfer into the cement-bound aggregate base layer through cracks in the surface pavement layer, so its negative impact must be controlled. From our measured results, we found that neither mixture met the requirements for frost-resistant materials. Thus, to produce frostresistant materials, one must use a cement of higher strength class or a higher cement ratio. Using steel slag can improve the strength of cement-bound gravel materials [15], and some preliminary results indicate that steel slag can improve the frost resistance of these materials.

\section{References}

[1] IGH 2001: General technical requirements for roadwork, in Book III, Pavement structure (in Croatian).

[2] Dore, G. 2002: Cold Region Pavements, Journal of Glaciology and Georyology, Volume 24, Issue 5, pp. 593-600.

[3] Sršen, M.; Kovačić, M.; Kaučić, D. 2003: Određivanje dubine smrzavanja tla ispod kolničke konstrukcije, Građevinar, Volume 56, Issue 3, pp. 145-154 (in Croatian).

[4] Babić, B. 1997: Projektiranje kolničkih konstrukcija, Hrvatsko društvo građevinskih inženjera, Zagreb (in Croatian)

[5] Jacobsen, S.; Sellevold, E. 1997: Frost/salt scaling and ice formation of concrete: effect of curing temperature and silica fume on normal and high strength concrete, Rilem Proceedings, Volume 30, FreezeThaw Durability of Concrete, pp. 93-105.

[6] Padilla, F.; Villeneuve, J.; Stein, J. 1997: Simulation and analysis of frost heaving in subsoils and granular fills of roads, Cold Regions Science and Technology, Volume 25, Issue 2, pp. 89-99.

[7] Si, W.; Ma, B.; Li, N.; Ren, J.; Wang, H. 2014: Reliability-based assessment of deteriorating performance to asphalt pavement under freeze-thaw cycles in cold regions, Construction and Building Materials, Volume 68, pp. 572-579.

[8] EN 13286-54 Unbound and hydraulically bound mixtures - Part 54: Test method for the determination of frost susceptibility - Resistance to freezing and thawing of hydraulically bound mixtures.

[9] HRN U.B1.050 Ispitivanje otpornosti cementom stabiliziranog tla na smrzavanje (in Croatian).

[10] Barišić, I. 2012: Composition optimization of pavement cement stabilized base courses with slag, Ph.D Thesis, Faculty of Civil Engineering, University of Zagreb (in Croatian).

[11] Ovad, E. 2014: Resistance to freezing and thawing of hydraulically bound mixtures, final thesis on the undergraduate professional study, course Road building and maintenance, Faculty of Civil Engineering Osijek, J.J. Strossmayer Univeristy of Osijek (in Croatian).

[12] Shen, W.; Zhou, M.; Ma, W.; Hu, J.; Cai, Z. 2009: Investigation on the application of steel slag-fly ashphosphogypsum solidified material as road base material, Journal of Hazardous Materials, Volume 164, Issue 1, pp. 99-104.

[13] Hale, W. M.; Freyne, S. F.; Bush Jr., T. D.; Russell, B. W. 2008: Properties of concrete mixtures containing slag cement and fly ash for use in transportation structures, Construction and Building Materials, Volume 22, Issue 9, pp. 1990-2000.

[14] Ismail, A.; Baghini, M. S.; Karim, M. R. B.; Shokri, F.; Al-mansoba, R. A.; Firoozi, A. A. 2014: Laboratory investigation on the strength characteristics of cement-treated base, Applied Mechanics and Materials, Volume 507, pp. 353-360.

[15] Barišić, I.; Dimter, S.; Rukavina, T. 2014: Strength properties of steel slag stabilized mixes, Composites: Part B, Volume 58, pp. 386-391. 